\title{
Elephant-mediated habitat modifications and changes in herbivore species assemblages in Sabi Sand, South Africa
}

\author{
Willem F. de Boer ${ }^{1}$ • Jordi W. A. Van Oort ${ }^{1} \cdot$ Michael Grover $^{2} \cdot$ Mike J. S. Peel $^{3}$
}

Received: 24 November 2014 /Revised: 19 April 2015 / Accepted: 22 April 2015 / Published online: 15 May 2015

(C) The Author(s) 2015. This article is published with open access at Springerlink.com

\begin{abstract}
Elephant Loxodonta africana conservation might indirectly influence the wider herbivore community structure, as elephants have the ability to significantly modify the savanna habitat. Uncertainty remains as to the consequences of these effects, as elephants might either compete with other species or facilitate foraging especially for grazers and smaller browsing species by increasing the amount of grass or the amount of browse at lower feeding heights. We studied these potential cascading effects of elephants by using 16 years of data (1992-2011) from the Sabi Sand Wildtuin, South Africa, which showed a steady increase in elephant densities from 0.12 to 2.03 elephants $/ \mathrm{km}^{2}$ over this period. We demonstrate that tree densities, and browse availability at feeding heights below $2 \mathrm{~m}$, decreased with increasing elephant densities, and that there was no positive effect of elephants on browse availability. The changes in elephant densities were good predictors $\left(R_{\text {adj }}^{2}>0.50\right)$ in explaining population fluctuations of other herbivore species. The total body mass of grazers increased more than that of the browsers, shifting the community toward a grazer and megaherbivore-dominated community. An increasing density of elephants changes the composition of the herbivore community, as mesobrowsers are unable to benefit from the impact of elephants on trees, but megagrazers show strong positive responses. Hence, changes in elephant
\end{abstract}

Communicated by M. Scandura

Willem F. de Boer

fred.deboer@wur.nl

1 Resource Ecology Group, Wageningen University, Droevendaalsesteeg 3a, 6708 PB Wageningen, The Netherlands

2 Sabi Sand Wildtuin, P.O. Box 105, Skukuza 1350, South Africa

3 Agricultural Research Council, Animal Production Institute, P.O. Box 7063, Nelspruit 1200, South Africa densities as a result of poaching or conservation may trigger cascading community effects. These are neglected but important consequences of (negative or positive) human impacts on elephant numbers, especially in restricted areas such as reserves and national parks.

Keywords Cascading effects · Competition · Facilitation · Keystone species · Tree density $\cdot$ Loxodonta africana

\section{Introduction}

The impact of African elephants (Loxodonta africana) on the occurrence and density of other herbivore species that share their savanna ecosystems is a highly controversial topic. Both negative and positive effects of elephants on other herbivore species have been claimed, as a consequence of the impact of elephants on the vegetation structure, biomass, and species composition. Elephants are known to push over, debark, and break trees, and various studies have found a decline in tree densities in the presence of elephants (Cumming et al. 1997; Shannon et al. 2008; Woolley et al. 2011). Even at comparatively low elephant densities $\left(<0.2\right.$ elephants $\left./ \mathrm{km}^{2}\right)$, the densities of certain tree species show signs of decline (Cumming et al. 1997; Shannon et al. 2008). By the early 2000s when elephant densities exceeded 0.5 animals $/ \mathrm{km}^{2}$ in the Kruger National Park (KNP), the extent of the woody layer in parts of the Park had shown significant decline (Whyte et al. 2003), and elephants are regarded as the primary agent of treefall, especially of trees in the 5-9-m height class (Asner and Levick 2012). In the proximity of large perennial rivers, current elephant densities in the KNP exceed 1.5 animals $/ \mathrm{km}^{2}$ (Smit and Ferreira 2010). Elephant impacts can also vary spatially and can be site- or context-dependent (Eckhardt et al. 2000; Guldemond and Van Aarde 2008). 
This impact of elephants on trees in the system has raised the concern of scientists and managers alike (Whyte et al. 1998; Van Aarde et al. 1999; Van Aarde et al. 2006; Kerley et al. 2008), as the decline in woody cover could negatively affect the browsing species in the system. Fritz et al. (2002) concluded that elephants compete with the smaller mesobrowser species for browse resources, as the relative contribution of these species declined with increasing elephant densities. Valeix et al. (2008) also reported a possible negative influence of elephants on other herbivore species. Elephant impact, especially on the larger trees, could also have negative consequences for large browsing species such as giraffe (Fritz et al. 2002).

Despite the fact that such studies have demonstrated that elephants have a detrimental effect on trees in savanna ecosystems, there is, however, also evidence for positive secondary effects of tree utilization by elephants. The preferred feeding height of elephants is $<2 \mathrm{~m}$ (Stokke and Du Toit 2000), and, in some cases, elephants appear to facilitate smaller browser species by increasing the quality and biomass availability of trees at lower feeding heights (Du Toit et al. 1990; Smallie and O'Connor 2000; Kohi et al. 2011; Kohi 2013). Further, impala (Aepyceros melampus) and kudu (Tragelaphus strepsiceros) benefitted from the conversion of woodland to shrubland by elephants in Botswana (Rutina et al. 2005; Makhabu et al. 2006). Elephants may even keep trees and shrubs below a certain maximum height by coppicing trees and shrubs, thus creating browsing lawns (Smallie and O'Connor 2000). Moreover, utilization by elephants can activate dormant buds, and as the number of buds is reduced by elephant browsing, the within-tree competition for resources decreases, resulting in fewer but larger shoots (Du Toit et al. 1990; Järemo et al. 1996). Some studies have suggested that some heavily browsed trees might not only produce higher quantities of foliage but also foliage of a higher quality (Du Toit et al. 1990; Smallie and O’Connor 2000; Kohi 2013). Regrowing shoots are often rich in nutrients and have relatively low concentrations of secondary compounds, turning them into high-quality forage resources which are more susceptible to rebrowsing (Price 1991; Kohi et al. 2011). So, once a tree has been browsed, the likelihood of it being rebrowsed increases (Skarpe et al. 2000). Browsed trees also retained their leaves further into the dry season, and hence, elephants may facilitate other browser species (Kohi 2013).

Grasses can benefit from the release of competition with trees (Scholes and Archer 1997; Fritz et al. 2002; van Langevelde et al. 2003), and opening up of woodlands could therefore have positive effects on grazing herbivores (Parker 1983; Kerley et al. 2008). However, a decrease in tree cover can also increase the visibility for prey and predators, and thereby influence the predation risk (Valeix et al. 2011).
In response to all these reported effects, one might anticipate negative effects of elephants on other browser species in the system at high elephant densities, but a potentially positive effect at low-intermediate densities. The opening up of the canopy and the decrease in tree densities are expected to positively influence the grazers over the entire elephant density gradient. None of the studies mentioned above, however, presented data at appropriate spatial and temporal scales to explore this question meaningfully. Here, we use a long-term data set with measures of tree height and density, as well as concurrent surveys estimating herbivore population sizes. These data were collected at the Sabi Sand WildtuinMalaMala complex, South Africa, between 1992 and 2011. We quantify the effect of elephants on the woody layer and test whether elephants were correlated with the population sizes of other herbivore species in the system. The elephant densities in Sabi Sand Wildtuin-MalaMala complex increased from 0.15 animals $/ \mathrm{km}^{2}$ in 1992 to 2.55 animals $/ \mathrm{km}^{2}$ in 2011. These annual monitoring data offer a unique opportunity to analyze the impact of elephants on the vegetation and, through that, on the rest of the herbivore community. It is envisaged that this will increase our understanding of how a natural herbivore community might change under the contrasting impacts of a successful conservation effort or increased poaching (de Boer et al. 2013).

Based on the considerations offered above, we expect that (i) mesobrowser species, such as common duiker (Sylvicapra grimmia), bushbuck (Tragelaphus scriptus), kudu, and steenbok (Raphicerus campestris), should increase at lowintermediate elephant densities, as they could benefit from the large availability of high quality browse at lower feeding heights and decrease at high elephant densities. (ii) The impala, an abundant mixed feeder (Kos et al. 2012) and the nyala (Tragelaphus angasii), are expected to track the mesobrowser response, because of their reliance on browse in their diet, although to a lesser extent than the pure browsers. Finally, as above, (iii) the opening up of the canopy and the decrease in tree densities is expected to positively influence the grazers over the entire elephant density gradient.

\section{Materials and methods}

\section{Study area}

The Sabi Sand Wildtuin-MalaMala complex (S $24^{\circ} 47^{\prime}$, E $31^{\circ}$ $29^{\prime}$ ), South Africa, covers an area of some $620 \mathrm{~km}^{2}$ and shares its northern and north-eastern boundaries with the Manyeleti Game Reserve and southern and eastern borders with the Kruger National Park (KNP). It is dominated by tall shrublands and moderately dense woodlands. The rainy season is from October to April and the region's mean annual precipitation calculated from July in the preceding year to 
June in the current year averaged $615 \mathrm{~mm}$ (1990-2011, SD= 234, three rainfall gauges at Gowrie, Shaws and Newington with monthly data cover the entire study 1991-2011). The mean total dry season rainfall, which has been correlated with elephant population growth and densities of other herbivore species (Ogutu and Owen-Smith 2003; Valeix et al. 2008), was calculated from May to September, averaging $38 \mathrm{~mm}$ $(\mathrm{SD}=24)$ over the study period. The complex is characterized by an Acacia and Combretum woodland, and more than $50 \%$ of all trees belong to only 8 species (in order of abundance): Combretum apiculatum, Dalbergia melanoxylon, Acacia exuvialis, Dichrostachys cinerea, Acacia nigrescens, Terminalia sericea, Ormocarpum trichocarpum, Albizia harveyi. Of the vegetation monitoring sites $(N=43), 30 \%$ were burned once every 30 to 15 years, $16 \%$ once every $10-8$ years, $21 \%$ once every $6-5$ years, $12 \%$ once every 4 years, and $21 \%$ once every 3 years, but fire tends to exert a smaller effect on the vegetation structure and heterogeneity than herbivory (Levick et al. 2009).

\section{Sampling}

The woody layer within the reserves was monitored annually in November-December from 1993 to 2011 by the Animal Production Institute of the Agricultural Research Council (ARC-API) using a $100 \times 2-\mathrm{m}$ belt transect in each of 43 permanent plots in which the number of all woody plants within a belt transect over four height classes (0-1.0, 1.1-2.0, 2.1-5.0, $>5.1 \mathrm{~m}$; Peel et al. 2005) was recorded, together with the numbers of stems per woody plant (recorded since 1995). The standing crop of the herbaceous layer was recorded from 1997 onward using a disk pasture meter which measures the herbaceous standing biomass in the presence of fire, herbivory, plant senescence, and decomposition (Zambatis et al. 2006).

Annual game counts have been done since 1992 in August-September, using a Bell Jet Ranger helicopter. The team consisted of a pilot and a front observer and two experienced back-seat observers who spot and count game. The front observer also records the data (species, totals, sex, and age where possible) on a computer linked to the helicopter's GPS thus providing a spatial distribution of the animals counted. The counts are carried out during winter months when foliage cover is at its lowest. The survey uses a strip width of $500 \mathrm{~m}$ (line lengths up to $15 \mathrm{~km}$ ) with continuous strips at an altitude of $90 \mathrm{~m}$ (Sutherland and Peel 2011). The mammal species present, together with their foraging characteristics, are listed in Table 1.

Fences between the Sabi Sand Wildtuin-MalaMala complex and KNP were dropped in 1993; so, changes in population densities are partly due to animal dispersal between the two protected area, and we were unable to distinguish between population growth and movements of animals to and from the area.

Since 2004, a total of about 2500 wildebeest (Connochaetes taurinus) have also been introduced in several batches in an effort to stabilize the wildebeest population, and the wildebeest population fluctuations were therefore not analyzed in detail. Data on the carnivore species were not available over the entire study period and could therefore not be included in the analysis. Small numbers of elephant, buffalo, and rhinos have also been removed from the area. On average, these represent $<3 \%$ of the population of each of the species and fall within the natural year-to-year variation of the species. These data were therefore excluded from the analysis.

Estimated predator population sizes were not available for the entire study period, but sometimes only for the last 4 years, and the impact of predators on prey population was therefore not analyzed further. The estimated population sizes were as follows: lion (Panthera leo) 105, leopard (Panthera pardus) 74, cheetah (Acinonyx jubatus) 15, spotted hyena (Crocuta crocuta) 66, and African wild dog (Lycaon pictus) 23.

\section{Data analysis}

To test for changes in browse availability over time, a regression that was initially undertaken of the overall stem density per square kilometer was first done. Analyses were then repeated on the four different height classes to determine the temporal trends in woody density and structure. To investigate whether a coppicing effect could be found, we tested if there was a significant increase in the mean number of stems per woody individual over time. We tested whether temporal changes in tree densities in different height classes were related to differences in elephant densities, using a multiple linear regression with woody density as the dependent variable and both elephant density and annual precipitation as independent variables.

To test whether the increasing elephant densities was correlated with a shift in the total browse and grass consumption of the entire herbivore assemblage, we calculated the combined annual food intake (DM, browse and grass) as $6.0 M-0.191^{*} 365^{*} \mathrm{~N}$ (Owen-Smith 1988), where $M$ is the species' body mass (Table 1 ), and $\mathrm{N}$ the number of animals per species. The percentages of browse and grass in the diet for each of the species were obtained from literature estimates (Table 1). To analyze the effect of elephants on the total proportion of browse and grass in the diet of entire herbivore assemblage, a regression was carried out with the proportion as the dependent variable and elephant density as the independent variable. This analysis was done without including the food consumption by elephants themselves to 
Table 1 The surveyed herbivores in the Sabi Sand Wildtuin-MalaMala complex with the percentage browse in their diet and their average weight (based on Codron et al 2007), and a comparison of total herbivore numbers per species in 1992, 1993, and 2011, and their contribution to the total food consumption in 1993 and 2011 (\%Food)

\begin{tabular}{|c|c|c|c|c|c|c|c|c|}
\hline Species & Common name & Feeding style & Average weight (kg) & $\begin{array}{l}\mathrm{N} \\
1992\end{array}$ & $\begin{array}{l}\mathrm{N} \\
1993\end{array}$ & $\begin{array}{l}\mathrm{N} \\
2011\end{array}$ & $\begin{array}{l}\text { \%Food } \\
1993\end{array}$ & $\begin{array}{l}\text { \%Food } \\
2011\end{array}$ \\
\hline Giraffa cameleopardalis $^{\dagger}$ & Giraffe & Browser & 1010 & 288 & 303 & 269 & 9.15 & 3.17 \\
\hline Tragelaphus scriptus ${ }^{*}$ & Bushbuck & Browser & 30 & 70 & 59 & 132 & $<0.01$ & $<0.01$ \\
\hline Sylvicapra grimmia ${ }^{*}$ & Common duiker & Browser & 19 & na & 103 & 49 & 0.12 & 0.02 \\
\hline Tragelaphus strepsiceros ${ }^{*}$ & Greater kudu & Browser & 140 & 573 & 862 & 901 & 5.26 & 2.15 \\
\hline Raphicerus campestris ${ }^{*}$ & Steenbok & Browser & 10 & na & 48 & 42 & 0.03 & 0.01 \\
\hline Loxodonta africana ${ }^{\dagger}$ & African elephant & Mixed feeder & 3750 & 73 & 60 & 1260 & 5.19 & 42.57 \\
\hline Tragelaphus angasii ${ }^{*}$ & Nyala & Mixed feeder & 73 & 157 & 171 & 418 & 0.62 & 0.59 \\
\hline Aepyceros melampus ${ }^{*}$ & Common impala & Mixed feeder & 41 & 14411 & 17776 & 10405 & 40.17 & 9.18 \\
\hline Syncerus caffer ${ }^{\dagger}$ & Buffalo & Grazer & 585 & 45 & 712 & 3464 & 13.82 & 26.25 \\
\hline 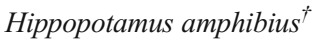 & Hippo & Grazer & 1406 & 160 & 31 & 320 & 1.22 & 4.93 \\
\hline Ceratotherium simum ${ }^{\dagger}$ & White rhino & Grazer & 1850 & 471 & 152 & 293 & 7.49 & 5.64 \\
\hline Phacochoerus africanus ${ }^{*}$ & Warthog & Grazer & 70 & 390 & 437 & 326 & 1.52 & 0.44 \\
\hline Kobus ellipsiprymnus ${ }^{*}$ & Waterbuck & Grazer & 220 & 753 & 388 & 439 & 3.41 & 1.51 \\
\hline Equus quagga burchellii ${ }^{*}$ & Zebra & Grazer & 320 & 927 & 816 & 627 & 7.05 & 2.11 \\
\hline Connochaetes taurinus ${ }^{*}$ & Wildebeest & Grazer & 215 & 882 & 571 & 423 & 4.93 & 1.43 \\
\hline
\end{tabular}

*Mesoherbivore

$\dagger$ Megaherbivore

better analyze the impact of elephant on the other grazer and browser species in the community.

The effect of elephant density and tree density on the density of the various herbivore species were also analyzed using regression. Changes over time or elephant impact effects might deviate from a linear relationship; so, linear regression, regression on log-transformed data, and exponential regressions were used, and the model with the highest $R^{2}$-adjusted and lowest AIC was selected. Residuals were tested for normality and analyzed for homoscedasticity.

As elephant and tree densities were highly collinear, we were unable to build a multiple regression model that included both elephant and tree densities as predictors to explain the changes of the other browser and grazer species. We therefore carried out a hierarchical partitioning, which is able to calculate the part of variation that is uniquely and in combination with other variables explained by a single explanatory variable (Chevan and Sutherland 1991; MacNally and Walsh 2004). The hierarchical partitioning was carried out for each of the herbivore species separately, using rainfall, year, tree density, and elephant density as predictors, but also included the total biomass consumption by all other grazer and all browser species as two additional predictor variables to represent the competition pressure from these two species groups. These latter two variables were calculated by excluding the species for which the analysis was carried out.
The hierarchical partitioning was carried out in R ( $R$ Development Core Team 2013) and the other tests in SPSS (v19).

\section{Results}

There was no significant effect of total annual rainfall on the grass standing biomass $(P>0.05)$. Because the differences in grass standing biomass were not significantly related to differences in numbers of any of the herbivore species and because it would reduce our analyses considerably, this variable was excluded from further analysis.

\section{Woody layer}

Overall tree density showed a significant decline over time $\left(F_{1,18}=100.951, P<0.001, R_{\text {adj }}^{2}=0.84 ;\right.$ Fig. 1$)$, and the number of stems per woody individual also declined $\left(F_{1,16}=\right.$ 64.715, $P<0.001, R_{\text {adj }}^{2}=0.80$; Fig. 1$)$. The woody density declined significantly in the $0-1.0,1.1-2.0$, and $>5.0 \mathrm{~m}$ height classes $\left(F_{1,18}>12.416, R_{\text {adj }}^{2}>0.39, P<0.003\right)$, but no changes were recorded in woody density in the $2.1-5.0 \mathrm{~m}$ height class. The density of larger trees $(>5.0 \mathrm{~m})$ declined from on average 261 trees/ha in the first 5 years to 79 trees/ha in the last 5 years (Fig. 1). 
Fig. 1 The changes over time in tree density (N/ha) of trees in different height classes: primary $y$-axis, broken lines: $0-1.0 \mathrm{~m}$, 1.1-2.0 m; secondary $y$-axis, solid lines: $2.1-5.0 \mathrm{~m},>5 \mathrm{~m}$; (a) stems per woody individual ( $\mathrm{N} /$ tree) and (b) elephant density $\left(\mathrm{N} / \mathrm{km}^{2}\right)$, (c) in the Sabi Sand Wildtuin
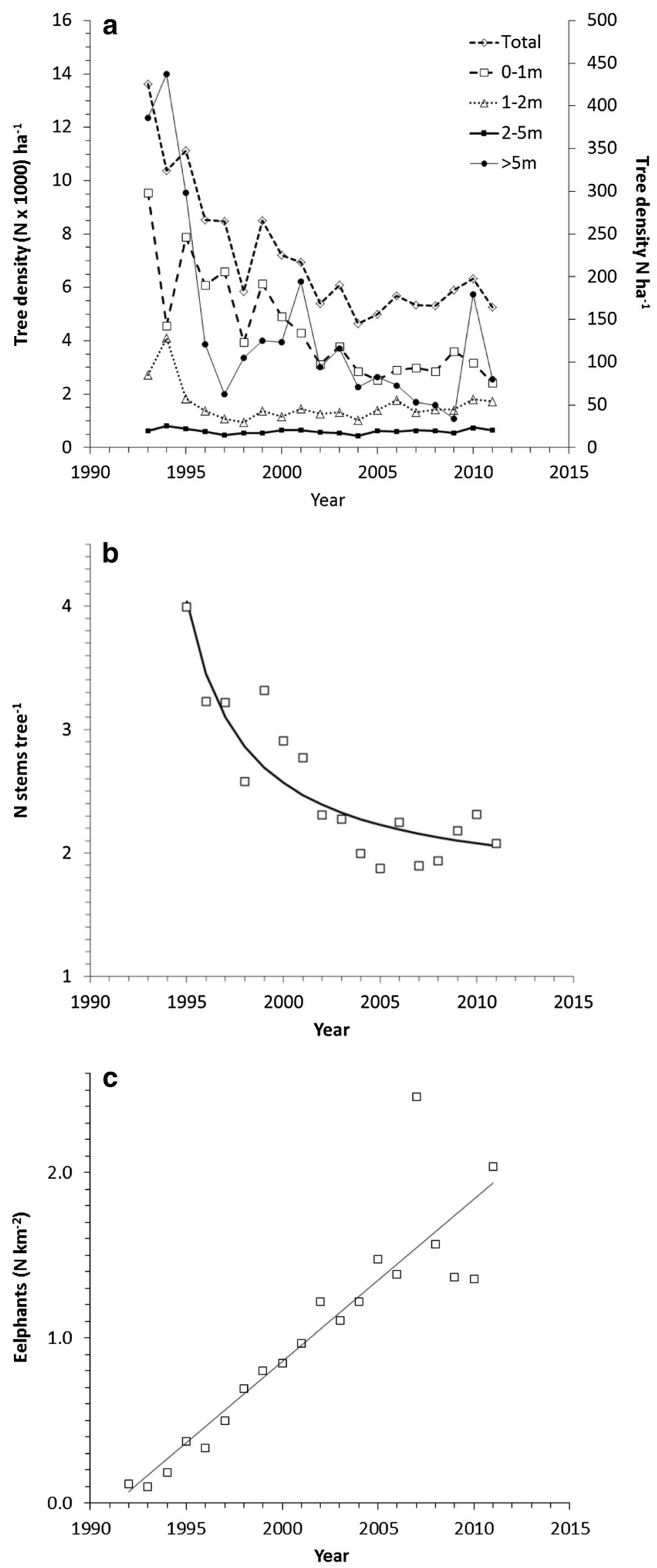


\section{Elephants and trees}

The elephant density increased over time from 0.12 elephants/ $\mathrm{km}^{2}$ in 1992 to 2.03 elephants $/ \mathrm{km} 2$ in $2011\left(F_{1,18}=88.514\right.$, $P<0.001, R^{2}$ adj=0.82, Fig. 1) from the combined effect of natural growth and mortality, and from migration from KNP. Although elephant densities seemed to stabilize in the last 2 years, a linear regression on the untransformed data yielded the best fit, i.e., the lowest AIC. The annual relative growth rate averaged $6.0 \%$ (range 5.3-6.8 \%) over the last 5 years of the study. However, this was much larger in the first 5 years of the study, averaging $57 \%$ per year (21.2-140.4\%), due largely to the influx of elephants from Kruger National Park.

The total annual precipitation of the current year alone, the preceding year alone, or the dry season rainfall $(P>0.10)$ could not statistically explain the differences in elephant density. Even if we assume that the changes in elephant numbers were caused mainly by the influx of elephants from Kruger National Park in the first years and thus restrict analysis to the data from 2003 onward, none of these three precipitation variables was significant in explaining elephant density.

Density of woody plants declined with increasing elephant density and a forward regression with both elephant density and annual total precipitation as independent variables showed that woody density was negatively correlated with elephant density $\left(F_{1,18}=98.550, P<0.001, R^{2}{ }_{\text {adj }}=2260.84\right.$, Fig. 2), but was not correlated with precipitation. Exploring the correlations between woody density in each height class and elephant density, we found that the woody structural classes of $0-1.0,1.1-2.0$, and $>5.0 \mathrm{~m}$ were all negatively correlated with elephant density (respectively, $F_{1,18}=43.203$, $P<0.001, R_{\text {adj }}^{2}=0.70 ; F_{1,18}=13.615, P=0.002, R_{\text {adj }}^{2}=0.41$; $\left.F_{1,18}=32.903, P<0.001, R_{\text {adj }}^{2}=0.64\right)$, but not the trees between 2.1 and $5.0 \mathrm{~m}$, as the tree density of trees between 2.1 and $5.0 \mathrm{~m}$ did not change over time. The number of stems per tree did not increase as was expected under a coppicing response, but in fact decreased with increasing elephant density $\left(F_{1,16}=55.093, P<0.001, R_{\text {adj }}^{2}=0.77\right.$; Fig. 2$)$. Assuming that there might be a time lag between the effect of elephant and/or the effect of rainfall on the woody density, we also used the elephant density and the annual rainfall in the preceding year as predictors, but this still did not increase the fit of the models.

\section{Elephants and other herbivore species}

In individual regression analyses, none of the browser species showed the expected hump-shaped relationship with highest densities at low to intermediate elephant densities (Fig. 3), i.e., no regression model yielded a significant positive main elephant density term and a negative squared term. Three browser species (duiker, steenbok, and giraffe; Fig. 3, Table 2) and the impala, a mixed feeder, declined with increasing elephant densities, and also, two grazer species (warthog and zebra) were negatively correlated with increasing elephant densities. However, the three megagrazers in the assemblage, buffalo, hippo, and white rhino also increased after the fence removal and were positively correlated with elephant numbers with a high $R_{\text {adj }}^{2}(>69 \%$; Table 2 ). Nyala and unexpectedly also bushbuck showed a significant positive relation with elephants. As expected, the relationships between the densities of herbivore species and the woody densities showed opposite coefficients to the elephant effect; for instance, the densities of the three megagrazer species were all negatively related to tree density (Table 2).

Hierarchical analysis was carried out on each species separately and calculated the percentage of explained variation for each of potential predictor variables and showed that elephant and trees densities were better predictors in explaining the changes in animal densities than year, rainfall, or the competition pressures from other browsing or grazing herbivore species (Fig. 4).

While, overall, total herbivore density decreased by $14 \%$ from 1993 to 2011, the total food consumption by herbivores increased by a factor 2.6, mainly due to the increase of elephants and other megagrazers (Table 1). Surprisingly, the total browse consumption by all herbivore species excluding elephant decreased from 44 to $30 \%$, and this percentage was strongly negatively correlated with the increasing elephant density (Fig. 2; current year elephant densities: $F_{1,17}=$ 65.362, $P<0.001, R^{2}$ adj $=0.78$; preceding year: $F_{1,16}=76.733$, $\left.P<0.001, R_{\text {adj }}^{2} 256=0.82\right)$. This decrease in browse consumption was accompanied by an inverse increase in grass consumption. Elephant density was a better predictor (larger $R^{2}$ adj) for the decrease in browse consumption than total tree density $\left(F_{1,17}=28.059, P<0.001, R_{\text {adj }}^{2}=0.60\right)$ or tree density in any of the 4 height classes $\left(0-1.0 \mathrm{~m}: F_{1,17}=29.455\right.$, $P<0.001, R_{\text {adj }}^{2}=0.61 ; 1.1-2.0 \mathrm{~m}: \mathrm{ns} ; 2.1-5.0: \mathrm{ns} ;>5.0 \mathrm{~m}$ : $\left.F_{1,17}=13.598, P<0.002, R_{\text {adj }}^{2}=0.41\right)$. However, there may also be a time lag in reaction, and indeed, the relationship with tree density improved considerably if the tree densities of the preceding year was used as the predictor variable in explaining the decrease in browse consumption (overall: $F_{1}$, ${ }_{16}=50.681, P<0.001, R_{\text {adj }}^{2}=0.75 ; 0-1.0 \mathrm{~m}: F_{1,16}=36.506$, $P<0.001, R_{\text {adj }}^{2}=0.68 ; 1.1-2.0 \mathrm{~m}: F_{1,16}=5.830, P=0.028$, $R_{\text {adj }}^{2}=0.22 ; 2.1-5.0: \mathrm{ns} ;>5.0 \mathrm{~m}: F_{1,16}=19.807, P<0.001$, $\left.R^{2}{ }_{\text {adj }}=0.53\right)$. However, comparing the AICs of the different models, the elephant density in the preceding year $(\mathrm{AIC}=$ 27.786) explained the decrease in browse consumption better than any of the other models $(\triangle \mathrm{AIC}>5)$.

\section{Discussion}

The question whether the relationship between elephants and other herbivores is facilitative or competitive is highly debated 
Fig. 2 Relationship between the elephant density $\left(\mathrm{N} / \mathrm{km}^{2}\right)$ and the overall tree stem density $\left(\mathrm{N} / \mathrm{km}^{2}\right)$ (a), the number of stems per tree (b) and the estimated total consumption of browse (filled squares) and grass (open squares) of the relevant herbivores depicted as a percentage of the total consumption excluding elephants in Sabi Sand WildtuinMalaMala complex (c)
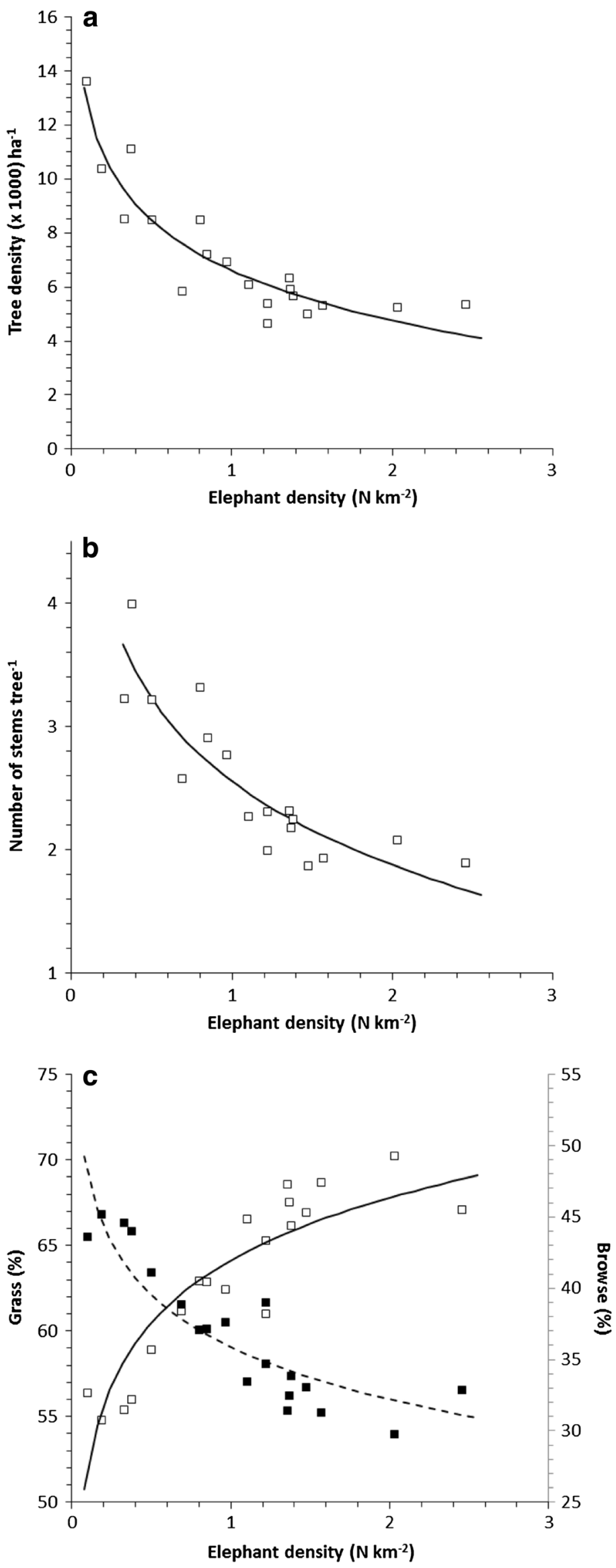

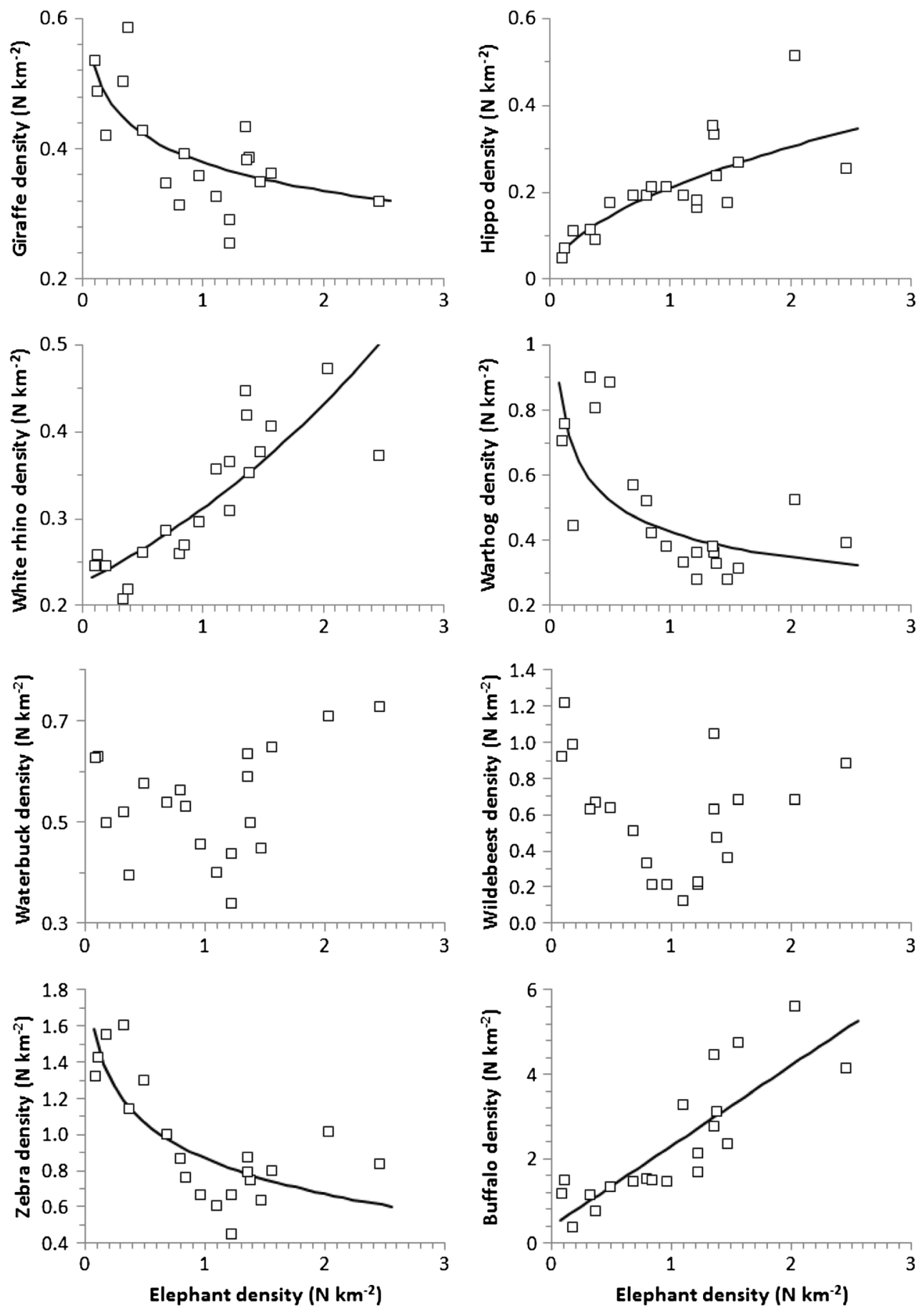

Fig. 3 The relationships between elephant densities in the Sabi Sand Wildtuin-MalaMala complex and the densities of other herbivore species $\left(\mathrm{N} / \mathrm{km}^{2}\right)$. Lines indicates best fit of significant models (Table 2)

(Fritz et al. 2002; Kohi et al. 2011; Valeix et al. 2011; Kohi 2013). The impact of elephant may be site- or contextdependent (Guldemond and Van Aarde 2008) and varies spatially within KNP (Eckhardt et al. 2000). Elephant numbers in the Sabi Sand Wildtuin-MalaMala complex were strongly negatively correlated with densities of both small and large trees. However, these correlations were not accompanied by a large coppicing response as predicted by some studies (Kohi et al. 2011; Smallie and O'Connor 2000), as the number of stems per tree as well as the number of trees $<1 \mathrm{~m}$ both decreased as tree damage increased. Consequently, the smaller browser species did not benefit from a coppicing response triggered by the large elephant browsing pressure. Interestingly, many previously published studies that suggest a facilitative effect of elephants on mesobrowsers base their findings on a specific (group of) woody species (Lewis 1991; 

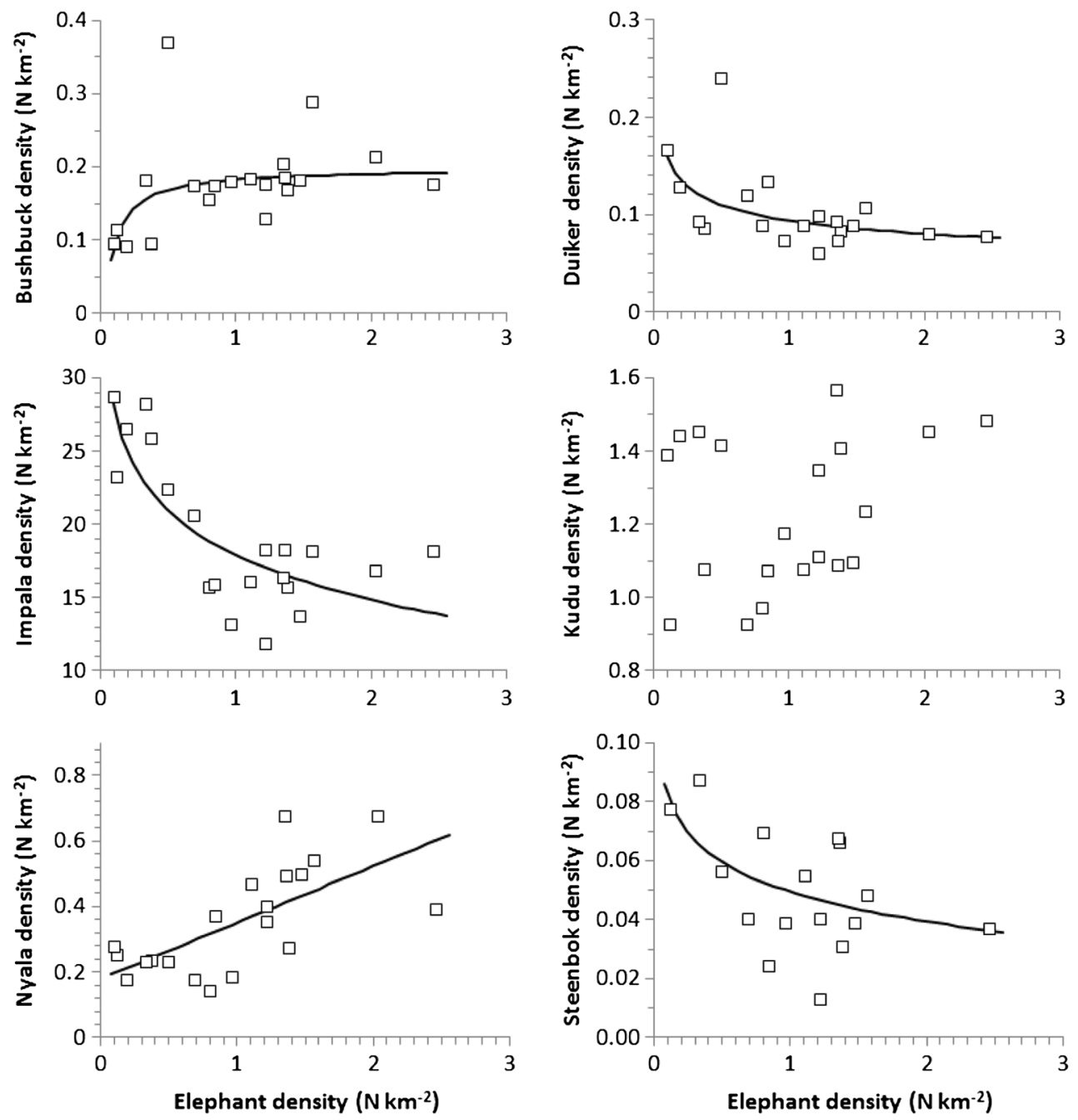

Fig. 3 (continued)

Smallie and O'Connor 2000; Rutina et al. 2005; Makhabu et al. 2006; Kohi et al. 2011). Kerley et al. (2008) suggested that the facilitative effects of elephants largely depend on the growth characteristics and other traits of the utilized species. Hence, the vegetation composition might play a pivotal role in defining the effect of elephants (Levick and Rogers 2008). This might also explain why in some areas, elephants seem to have a facilitative effect whereas in other areas, they show a competitive effect. The decline in the proportion of browsers in Sabi Sand Wildtuin-MalaMala complex might therefore be mediated by the granite lowveld and the Combretum spp. vegetation in the area, in which the common woody vegetation does not reach stem densities as high as the stem density in mopane woodlands after being utilized by elephants (Witkowski and O'Connor 1996). The relatively lower stem density and survival rate after elephant utilization probably lead to more open woodlands in the granite lowveld.

The negative correlation between elephant numbers and tree densities in most height classes in our study area, and in other areas (Cumming et al. 1997; Whyte et al. 2003; Shannon et al. 2008; Woolley et al. 2011), together with the population changes of the browser and grazer species, indicate in this instance that elephant might compete with other browsing species and facilitate grazers, especially megagrazer species, i.e., hippo, white rhino, and buffalo, through a decrease in tree cover and an increase in grass. Also, the proportion of browse consumed by other herbivores, aside from elephant, decreased over time. Therefore, our results suggest that with increasing elephant densities, the herbivore community shifts toward one dominated by grazers and with a smaller contribution of browsers. Hence, successful elephant conservation (an increase in elephant numbers) or poaching (strong decrease in numbers; de Boer et al. 2013) could trigger cascading community effects.

The number of elephant in the area increased 17-fold from 1992 to 2011 (Table 1), whereas the total animal density decreased slightly from 36 to 31 animals $/ \mathrm{km}^{2}$ from 1993, when the fences were dropped, to 2011. Some species did not benefit from the removal of fences between the Kruger National Park and Sabi Sand Wildtuin-Mala Mala complex, and some 
Table 2 Regression results for each of the herbivore species with elephants and tree density, respectively, as the single predictor variable (d.f., sign of the regression coefficient, $R_{\text {adj }}^{2}, F$, and $P$ value)

\begin{tabular}{|c|c|c|c|c|c|c|c|c|c|c|c|}
\hline \multirow[t]{2}{*}{ Common name } & \multicolumn{5}{|c|}{ Elephant } & \multicolumn{6}{|l|}{ Trees } \\
\hline & d.f. & $+/-$ & $R_{\text {adj }}^{2}$ & $F$ & $P$ & d.f. & Class & $+/-$ & $R_{\text {adj }}^{2}$ & $F$ & $P$ \\
\hline African elephant & & na & & & & 1,17 & all & - & 0.84 & 98.550 & $<0.001$ \\
\hline Bushbuck & 1,17 & + & 0.35 & 11.024 & 0.004 & 1,17 & $>5$ & - & 0.55 & 22.563 & $<0.001$ \\
\hline Common duiker & 1,18 & - & 0.30 & 8.603 & 0.009 & 1,17 & $<1$ & + & 0.24 & 6.524 & 0.021 \\
\hline Common impala & 1,18 & - & 0.63 & 32.238 & $<0.001$ & 1,17 & all & + & 0.57 & 24.649 & $<0.001$ \\
\hline Greater kudu & 1,18 & $\mathrm{~ns}$ & & & & & ns & & & & \\
\hline Nyala & 1,18 & + & 0.43 & 15.165 & 0.001 & 1,17 & $<1$ & - & 0.45 & 15.553 & 0.001 \\
\hline Steenbok & 1,14 & - & 0.23 & 5.419 & 0.035 & 1,14 & $<1$ & + & 0.23 & 5.448 & 0.035 \\
\hline Giraffe & 1,18 & - & 0.43 & 15.317 & 0.001 & 1,17 & all & + & 0.37 & 11.353 & 0.004 \\
\hline Buffalo & 1,18 & + & 0.69 & 42.312 & $<0.001$ & 1,17 & $<1$ & - & 0.52 & 20.491 & $<0.001$ \\
\hline Hippo & 1,18 & + & 0.78 & 69.644 & $<0.001$ & 1,17 & all & - & 0.63 & 31.151 & $<0.001$ \\
\hline White rhino & 1,18 & + & 0.71 & 46.431 & $<0.001$ & 1,17 & $<1$ & - & 0.71 & 45.755 & $<0.001$ \\
\hline Warthog & 1,18 & - & 0.46 & 16.835 & 0.001 & 1,17 & $<1$ & + & 0.59 & 26.825 & $<0.001$ \\
\hline Waterbuck & 1,18 & $\mathrm{~ns}$ & & & & 1,17 & ns & & & & \\
\hline Wildebeest & & na & & & & & na & & & & \\
\hline Zebra & 1,18 & - & 0.60 & 28.963 & $<0.001$ & 1,17 & all & + & 0.54 & 21.937 & $<0.001$ \\
\hline
\end{tabular}

There were three trees classes used as predictors (all: all trees; $<1: 0-1 \mathrm{~m} ;>5:>5 \mathrm{~m}$ ); only the regression results with the highest $R^{2}$ adj are reported here na not applicable, $n s$ not significant

species such as duiker, steenbok and giraffe (browsers), and zebra and warthog (grazers) even declined. However, the total metabolic mass of browsers (excluding elephants) increased by a factor of 1.2 between 1992 and 2011, whereas the total mass of grazers increased by 1.7. Thus, while the actual number of animals decreased, all guilds apparently benefitted in terms of total body mass from the removal of the fences. This increase in consumption is particularly caused by the increase of megaherbivores, since the mesoherbivore densities declined or showed relatively small increases. The grazers benefitted proportionately more from the fence removal and elephant increase, and the community therefore shifted toward a more elephant- and megagrazer-dominated system.

In our correlative approach, we are unable to determine the cause-effect relationships, and changes in elephant densities may covary with other variables. For instance, the decrease in
Fig. 4 The results of the hierarchical partitioning as depicted by the total contribution (independent and its conjoint contribution $\pm \mathrm{SD}$ ) of each of the predictors in a set of regression equations as averaged for all browser ( $N=5$; giraffe, steenbok, duiker, bushbuck, kudu), grazer ( $N=6$; white rhino, buffalo, hippo, warthog, zebra, waterbuck), and mixed feeder species $(N=2$; nyala, impala), excluding elephants. The used predictor variables were elephant density, year, rainfall, tree density (all trees and only $<1 \mathrm{~m}$ ), and the total biomass consumption by all other browser and grazers species (Browser C, Grazer C) to represent the competition pressure from these two species groups

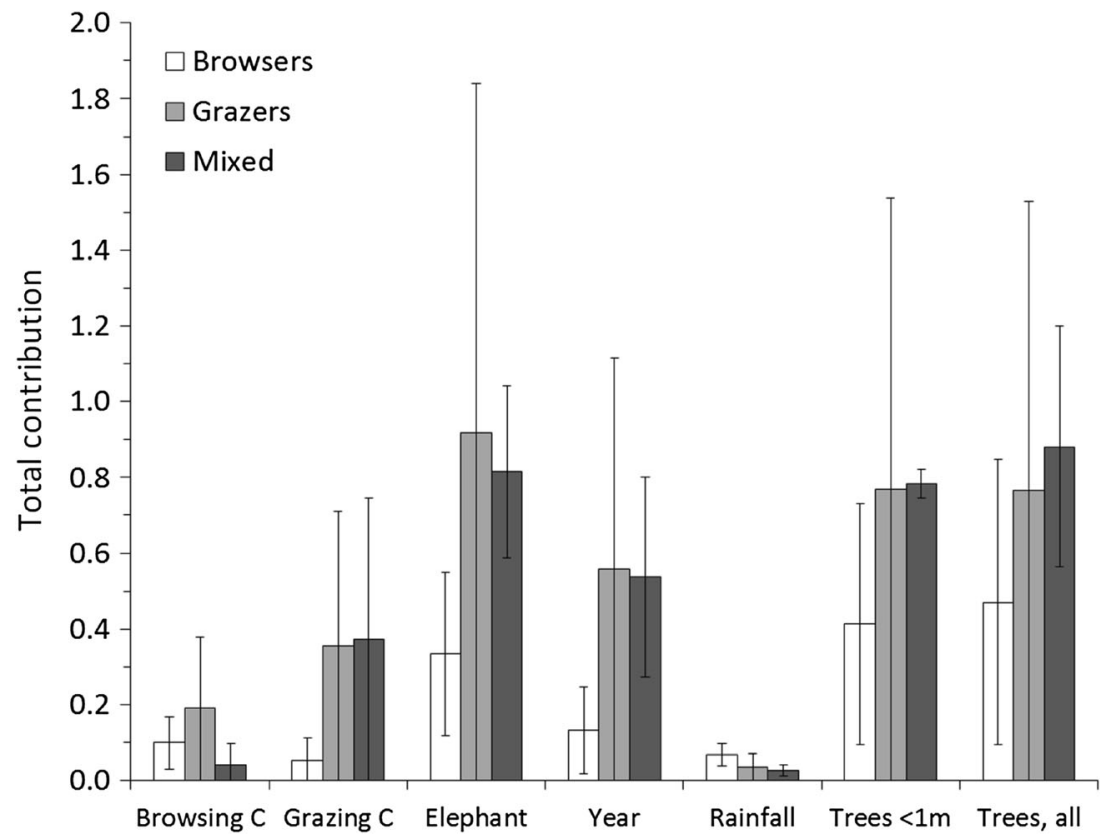


stem density and the removal of the larger trees in particular might not only increase the frequency and intensity of fires (Govender et al. 2006), but also decrease the facilitative role of trees on grasses by decreasing the role of large trees as nutrient pumps (Treydte et al. 2007). This could be one of the mechanisms that stimulate growth of nutrient poor grasses that can only be used by megagrazers and are of too poor a quality for mesograzers (Olff et al. 2002). Fires certainly play a big role in structuring African savannas (Higgins et al. 2000; Govender et al. 2006) and contribute to the decline in small trees through fire-related mortality. So, the underlying mechanisms explaining the differences in the herbivore community might, besides the direct competition for food or the dispersal after the removal of fences, also be explained by the indirect effects of elephants on the grass layer which indirectly influences the fire regime and food quality.

The changes in herbivore species densities in relation to increasing elephant and decreasing tree densities differed between species. Skarpe et al. (2004) has shown that structural changes due to elephants benefited certain browsing species while others showed a decline in density. The opening up of vegetation by elephants seemed especially beneficial to the megagrazers, with buffalo, hippo, and white rhino numbers being strongly positively correlated with elephant density. Zebras showed a negative correlation with elephant density, suggesting the possibility of resource competition (Young et al. 2005). Bulk feeders do not usually compete with mesograzers such as zebra (Sinclair and Norton-Griffiths 1982), but interspecific competition between mega- and mesograzers could occur during the dry season (Arsenault and Owen-Smith 2002). The differences in response between mega- and mesograzers might also be mediated by fire and a decrease in forage quality, being better tolerated by megarather than by mesoherbivores such as zebra. A species that showed a strong negative relation with elephant density and a positive relation with tree density was the giraffe. The decline in giraffe observed in this study was likely to be due to the fact that an increase in elephant numbers was associated with a decline in tall trees. Fritz et al. (2002) suggested that giraffes in particular could suffer from increasing elephant densities as the amount of vegetation at their preferred feeding height decreased, although, as with zebra, predation could also be important in explaining their decline.

In this study, impala density was negatively correlated to the increasing number of elephant. According to Fritz et al. (2002) and Valeix et al. (2008), elephants may compete with mesomixed feeders (such as impala), depending on the abundance and quality of the forage. However, Sinclair et al. (2003) showed that predation is a factor defining herbivore densities on African savannas, particularly for small herbivores $(<150 \mathrm{~kg})$. The change in vegetation structure could affect the predation risk of a species; the opening up of the landscape increases the visibility and is expected to decrease the predation risk (Valeix et al. 2011). The decrease in impala densities in our study is not easily explained by increased visibility as a consequence of the lower tree density, but predation could play a role here through a larger success of cursorial predators, such as the cheetah, in a more open landscape. So, whether the negative relationship between impala and elephant densities is due to direct resource competition with elephants, competition with other herbivore species, changes in predation pressure or other factors, needs to be studied in more detail. Some studies have reported a negative effect of impala on tree recruitment (O'Kane et al. 2012; Prins and Van Der Jeugd 1993) through their impact on seed and seedling survival. However, tree density of small trees $(<1 \mathrm{~m})$ was positively correlated with impala density in our study $\left(F_{1}\right.$, ${ }_{17}=17.197, P=0.001, R_{\text {adj }}^{2}=0.47$ ).

Elephant populations show large positive and negative changes worldwide as a consequence of successful conservation efforts or increasing poaching activities (de Boer et al. 2013). Our results suggest that these changes can trigger cascading community effects. These effects may not always have been noticed by park managers as they typically take a long period before they become apparent. Future efforts to understand the effects of elephants on herbivores should therefore target and compare specific areas to better understand the impact that elephant have on savanna systems, and the causal mechanisms behind observed changes.

Acknowledgments We thank John Peel, Andre Jacobs, Lucas Manaka, and Hennie de Beer for their tireless efforts in the field as well as with data capture and collation. Sweetness Myeni is thanked for her assistance with logistics and administration. The landowners, management and staff of the Sabi Sand Wildtuin, former CEO Andrew Parker, and the owners of Mala Mala, Mike Rattray, Alison Morphet, and David Evans, are thanked for their support. Richard Pettifor for his comments on an earlier draft and Professors Norman Owen-Smith and Rory Putman for their constructive reviews.

\section{Compliance with ethical standards}

Conflict of interest No potential conflicts of interest have been identified.

Human and animal rights and informed consent This study was carried out without handling animals, using existing survey data.

Open Access This article is distributed under the terms of the Creative Commons Attribution 4.0 International License (http:// creativecommons.org/licenses/by/4.0/), which permits unrestricted use, distribution, and reproduction in any medium, provided you give appropriate credit to the original author(s) and the source, provide a link to the Creative Commons license, and indicate if changes were made.

\section{References}

Arsenault R, Owen-Smith N (2002) Facilitation versus competition in grazing herbivore Assemblages. Oikos 97:313-318 
Asner GP, Levick SR (2012) Landscape-scale effects of herbivores on treefall in African savannas. Ecol Lett 15:1211-1217

Chevan A, Sutherland M (1991) Hierarchical partitioning. Am Stat 45: 90-96

Codron D, Codron J, Lee-Thorp JA, Sponheimer M, De Ruiter D, Sealy J, Grant R, Fourie N (2007) Diets of savanna ungulates from stable carbon isotope composition of faeces. J Zool 273:21-29

Cumming DHM, Fenton MB, Rautenbach IL, Taylor RD, Cumming GS, Cumming MS, Dunlop JM, Ford GS, Hovorka MD, Johnston DS, Kalcounis MC, Mahlanga Z, Portfors CV (1997) Elephants, woodlands and biodiversity in miombo woodland in southern Africa. $\mathrm{S}$ Afr J Sci 93:231-236

de Boer WF, van Langevelde F, Prins HHT, de Ruiter PC, Blanc J, Vis MJP, Gaston KJ, Hamilton ID (2013) Understanding spatial differences in African elephant densities and occurrence, a continent-wide analysis. Biol Conserv 159:468-476

Du Toit JT, Bryant JP, Frisby K (1990) Regrowth and palatability of Acacia shoots following pruning by African savanna browsers. Ecology 71:149-154

Eckhardt HC, Wilgen BW, Biggs HC (2000) Trends in woody vegetation cover in the Kruger National Park, South Africa, between 1940 and 1998. Afr J Ecol 38:108-115

Fritz H, Duncan P, Gordon I, Illius A (2002) Megaherbivores influence trophic guilds structure in African ungulate communities. Oecologia 131:620-625

Govender NWSW, Trollope WSW, Van Wilgen BW (2006) The effect of fire season, fire frequency, rainfall and management on fire intensity in savanna vegetation in South Africa. J Appl Ecol 43:748-758

Guldemond R, Van Aarde R (2008) A meta-analysis of the impact of African elephants on savanna vegetation. J Wildlife Manag 72: 892-899

Higgins SI, Bond WJ, Trollope WSW (2000) Fire, resprouting and variability: a recipe for grass-tree coexistence in savanna. J Ecol 88: 213-229

Järemo J, Nilsson P, Tuomi J (1996) Plant compensatory growth: herbivory or competition? Oikos 77:238-247

Kerley GIH, Landman M, Kruger L, Owen-Smith N, Balfour D, de Boer WF, Gaylard A, Lindsey K, Slotow R (2008) Effects of elephants on ecosystem en biodiversity. In: Scholes RJ, Mennell GG (eds) Elephant management; a scientific assessment for South Africa. Wits University Press, Johannesburg, pp 146-205

Kohi EM (2013) The bulldozer herbivore: how animals benefit from elephant modifying an African savanna. $\mathrm{PhD}$ thesis, Wageningen University, Wageningen

Kohi EM, de Boer WF, Peel MJS, Slotow R, van der Waal C, Heitkönig IMA, Skidmore A, Prins HHT (2011) African elephants Loxodonta africana amplify browse heterogeneity in African savanna. Biotropica 43:711-721

Kos M, Hoetmer A, Pretorius Y, de Boer WF, Knegt H, Grant CC, Kohi E, Page B, Peel M, Slotow R, van der Waal C, Wieren S, Prins HT, van Langevelde F (2012) Seasonal diet changes in elephant and impala in mopane woodland. Eur J Wildl Res 58:279-287

Levick S, Rogers K (2008) Patch and species specific responses of savanna woody vegetation to browser exclusion. Biol Conserv 141: 489-498

Levick SR, Asner GP, Kennedy-Bowdoin T, Knapp DE (2009) The relative influence of fire and herbivory on savanna three-dimensional vegetation structure. Biol Conserv 142:1693-1700

Lewis D (1991) Observations of tree growth, woodland structure and elephant damage on Colophospermum mopane in Luangwa Valley, Zambia. Afr J Ecol 29:207-221

MacNally R, Walsh CJ (2004) Hierarchical partitioning public-domain software. Biodiversity Conserv 13:659-660

Makhabu SW, Skarpe C, Hytteborn H (2006) Elephant impact on shoot distribution on trees and on rebrowsing by smaller browsers. Acta Oecol 30:136-146
Ogutu JO, Owen-Smith N (2003) ENSO, rainfall and temperature influences on extreme population declines among African savanna ungulates. Ecol Lett 6:412-419

O'Kane CAJ, Duffy KJ, Page BR, Macdonald DW (2012) Heavy impact on seedlings by the impala suggests a central role in woodland dynamics. J Trop Ecol 28:291-297

Olff H, Ritchie ME, Prins HHT (2002) Global environmental controls of diversity in large herbivores. Nature 415:901-904

Owen-Smith RN (1988) Megaherbivores, the Influence of Very Large Body Size on Ecology. Cambridge University Press, New York

Parker ISC (1983) The Tsavo story: an ecological case history. In: OwenSmith N (ed) Management of large mammals in African conservation areas. Haum, Pretoria, pp 37-50

Peel MJS, Kruger JM, Zacharias PJK (2005) Environmental and management determinants of vegetation state on protected areas in the eastern Lowveld of South Africa. Afr J Ecol 43:352-361

Price PW (1991) The plant vigor hypothesis and herbivore attack. Oikos 62:244-251

Prins HHT, Van Der Jeugd HP (1993) Herbivore population crashes and woodland structure in East Africa. J Ecol 81:305-314

R Development Core Team (2013) R: a language and environment for statistical computing. The R Foundation for Statistical Computing, Vienna

Rutina LP, Moe SR, Swenson JE (2005) Elephant Loxodonta africana driven woodland conversion to shrubland improves dry-season browse availability for impalas Aepyceros melampus. Wildl Biol 11:207-213

Scholes RJ, Archer SR (1997) Tree-grass interactions in savannas. Annu Rev Ecol Syst 28:517-544

Shannon G, Druce DJ, Page BR, Eckhardt HC, Grant R, Slotow R (2008) The utilization of large savanna trees by elephant in southern Kruger National Park. J Trop Ecol 24:281-289

Sinclair ARE, Norton-Griffiths M (1982) Does competition or facilitation regulate migrant ungulate populations in the Serengeti? A test of hypotheses. Oecologia 53:364-369

Sinclair ARE, Mduma S, Brashares JS (2003) Patterns of predation in a diverse predator-prey system. Nature 425:288-290

Skarpe C, Bergström R, Bråten AL, Danell K (2000) Browsing in a heterogeneous savanna. Ecography 23:632-640

Skarpe C, Aarrestad PA, Andreassen HP et al (2004) The return of the giants: ecological effects of an increasing elephant population. Ambio 33:276-282

Smallie JJ, O'Connor TG (2000) Elephant utilization of Colophospermum mopane: possible benefits of hedging. Afr $\mathrm{J}$ Ecol 38:352-359

Smit IPJ, Ferreira SM (2010) Management intervention affects riverbound spatial dynamics of elephants. Biol Conserv 143:2172-2181

Stokke S, du Toit JT (2000) Sex and size related differences in the dry season feeding patterns of elephants in Chobe National Park, Botswana. Ecography 23:70-80

Sutherland WJ, Peel MJS (2011) Benchmarking as a means to improve conservation practice. Oryx 45:56-59

Treydte AC, Heitkönig IMA, Prins HHT, Ludwig F (2007) Trees improve grass quality for herbivores in African savannas. Perspect Plant Ecol 8:197-205

Valeix M, Fritz H, Chamaillé-Jammes S, Bourgarel M, Murindagomo F (2008) Fluctuations in abundance of large herbivore populations: insights into the influence of dry season rainfall and elephant numbers from long-term data. Anim Conserv 11:391-400

Valeix M, Fritz H, Sabatier R, Murindagomo F, Cumming D, Duncan P (2011) Elephant-induced structural changes in the vegetation and habitat selection by large herbivores in an African savanna. Biol Conserv 144:902-912

Van Aarde R, Whyte I, Pimm S (1999) Culling and the dynamics of the Kruger National Park African elephant population. Anim Conserv 2: 287-294 
Van Aarde RJ, Jackson TP, Ferreira SM (2006) Conservation science and elephant management in southern Africa. S Afr J Sci 102:385-388

Van Langevelde F, van de Vijver CADM, Kumar L, van de Koppel J, de Ridder N, van Andel J, Skidmore AK, Hearne JW, Stroosnijder L, Bond WJ, Prins HHT, Rietkerk M (2003) Effects of fire and herbivory on the stability of savanna ecosystems. Ecology 84:337-350

Whyte I, van Aarde R, Pimm SL (1998) Managing the elephants of Kruger National Park. Anim Conserv 1:77-83

Whyte IJ, van Aarde RJ, Pimm SL (2003) Kruger's elephant population: Its size and consequences for ecosystem heterogeneity. In: Du Toit J, Rogers KH, Biggs HC (eds) The Kruger experience. Island Press, Washington, pp 332-348
Witkowski ETF, O’Connor TG (1996) Topo-edaphic, floristic and physiognomic gradients of woody plants in a semi-arid African savanna woodland. Vegetatio 124:9-23

Woolley L-A, Page B, Slotow R (2011) Foraging strategy within African elephant family units: why body size matters. Biotropica 43:489 495

Young TP, Palmer TM, Gadd ME (2005) Competition and compensation among cattle, zebras, and elephants in a semi-arid savanna in Laikipia, Kenya. Biol Conserv 122:351-359

Zambatis N, Zacharias PJK, Morris CD, Derry JF (2006) Re-evaluation of the disc pasture meter calibration for the Kruger National Park, South Africa. Afr J Range For Sci 23:85-97 